\title{
Valorization of Catla Visceral Waste by Obtaining Industrially Important Enzyme: Trypsin
}

\author{
Charu Batav* and Ragini Gothalwal \\ Department of Biotechnology, Barkatullah University, India
}

Submission: November 11, 2020; Published: November 20, 2020

*Corresponding author: Charu Batav, Department of Biotechnology, Barkatullah University, Bhopal, India

\begin{abstract}
The fish visceral waste is currently posing a major problem to fisheries and environment sustainability. India has generated fish waste around $50 \%$ of the production in the year 2015-16. The indiscriminate practices of waste disposal cause physical and ecological imbalances in the ecosystem. Hence, its management has become very important. The visceral organs are known sources of biologically active compounds therefore, value-added products can be recovered. The present study focused on isolation of visceral protease of popular fish species, Catla catla. The proteins were precipitated using various precipitating agents among which cold acetone was found best (152.93mg ml-1 protein). The kinetic study of the enzyme was performed using BAPNA substrate and enzyme activity (15.54 U ml-1), Km $(2.47 \mathrm{mM})$ and Vmax $(0.40 \mu \mathrm{m}-1 \mathrm{~min}-$ 1) were calculated. The molecular weight of the protease was $24 \mathrm{KDa}$, optimum $\mathrm{pH}$ was 8.5 , and optimum temperature was $40^{\circ} \mathrm{C}$. The enzyme was found $19.3 \%$ similar with mammalian (bovine) trypsin. Henceforth, the enzyme was thought to solve the fish visceral waste problem with an ecological approach.
\end{abstract}

Keyword: Fish visceral waste; Protease; Trypsin; Enzyme kinetics; Lineweaver-Burke plot; SDS-Page

Abbreviations: BSE: Bovine Spongiform Encephalopathy; BSA: Bovine Serum Albumin; TIC: Total Ion Current Chromatogram

\section{Introduction}

Trypsin (EC 3.4.21.4) a serine peptidase, is prevalent throughout the animal kingdom. It digests the proteins and peptides by attacking at the Lys and Arg residues from their carboxyl end. It is synthesized as trypsinogen, as an inactive form by the pancreas into the intestine where it activates other intestinal enzymes along with itself Kanno [1]. The catalytic triad of trypsin is made up of Ser, His and Asp and has a negative charged pocket to recognize positive charged residue of substrate. Thus, Arginine derivatives are used as substrates to study trypsin activity. So far, many mammalian trypsin has been studied, but fish trypsin possesses a high catalytic activity even at low temperature. This unique property makes their applicability in many industries and biotechnology Victor dos Santos [2]. Moreover, fish visceral waste can be valorized optimally by obtaining visceral protease trypsin Aissaoui [3]. The economic importance of waste derived trypsin can be assessed by the fact that the waste can be utilized in a costeffective manner Das et al. [4]. According to Klomklao \& Benjakul fish visceral waste produced upon processing of fish, comprises around $20-30 \%$ of the fish weight.

Fish trypsin from diverse habitats has been isolated including marine, freshwater and gulf. Wang et al. [5] have purified and characterized trypsin from hybrid tilapia Oreochromis niloticus $\mathrm{x}$ 0 . aureus. Trypsin exclusively from fish waste has been isolated by Jellouli et al. [6]; Silva et al. [7]; Unajak et al. [8]; Costa et al. [9]; Blanco et al. [10]; Khandagale et al. [11]. The application of fish waste-derived trypsin in industries demands its compatibility with commercial (bovine) trypsin. This existing source carries a high risk of bovine spongiform encephalopathy (BSE). In this context, fish waste-derived trypsin can prove to be a safer alternative. Thus, scientists compare trypsin for different sources on the basis of activity, amino acid sequence and structure Toyota et al. [12]. The present study focused upon isolating and purifying trypsin from visceral waste of freshwater fish Catla catla, one of the most preferred Indian major carps. The purified enzyme was characterized by studying enzyme kinetics and measuring kinetic parameters. Also, assessment of its potential industrial application was done using a high throughput proteomic technique 0-HRLCMS. This as a 'bottom-up' approach, used to identify the MS spectra of the peptides by generating a sequence coverage map. Based upon this map, the similarity with commercial trypsin was established. Besides, using bioinformatics tool, BLAST, similarity with other fish trypsin was also recognized. 


\section{Materials and Methods}

\section{Sampling}

Sampling was performed at 4 different local fish markets of Bhopal (Banjari fish market, Bittan market area, Kotra Sultanabad fish market and Shahpura fish market). The fishes identified as Catla catla using an online database Fish Base. Adult healthy fishes weighing $2 \mathrm{Kg}( \pm 0.5)$ and were collected during post- monsoon and pre-monsoon seasons. Their visceral waste liver and intestine (Figure 1) were without delay kept in an ice-box and then transferred to Molecular Biology Laboratory, Department of Biotechnology, Barkatullah University, Bhopal. From the waste $100 \mathrm{~g}$ liver and 100g intestine (Axis LC/GC weighing balance) was excised, washed with $0.8 \%$ saline, labeled and stored at $-20^{\circ} \mathrm{C}$ for further use.

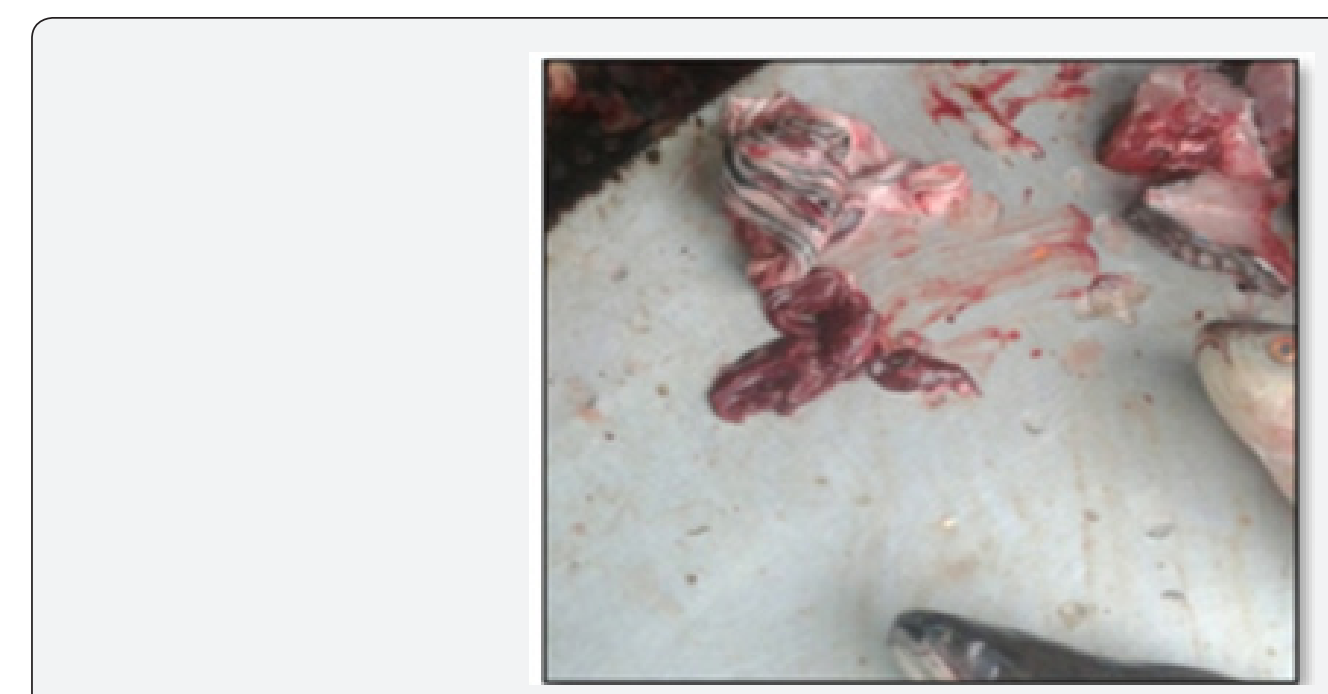

Figure 1: Viscera.

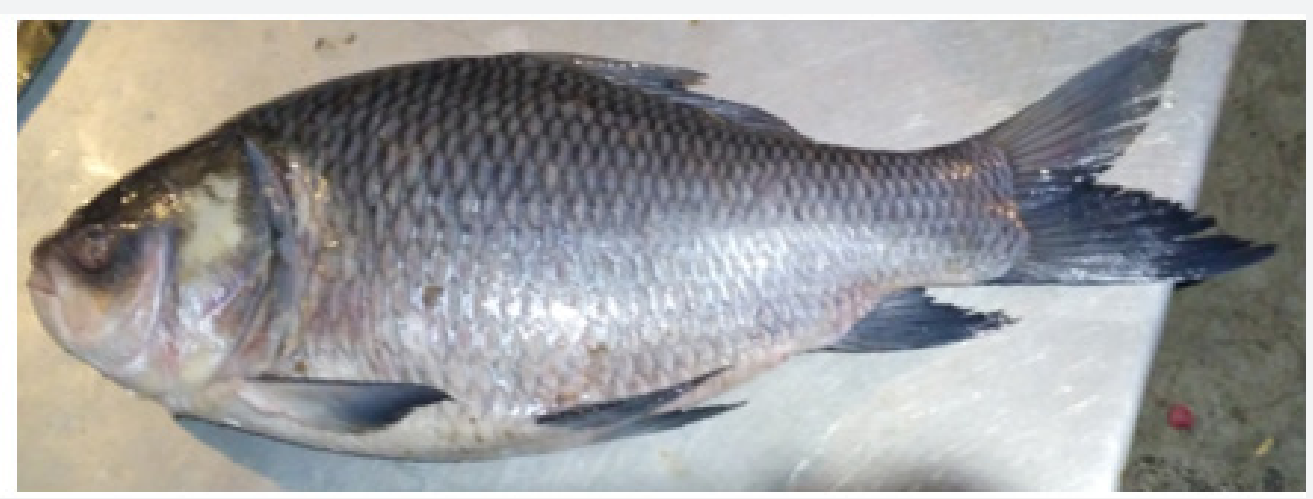

Figure 2: Catla catla (Catla).

\section{Preparation of crude enzyme extract}

Using the method of Simpson \& Haard [13], A 10\% homogenate of liver and intestine was prepared in extraction buffer ( $1 \mathrm{mM}$ Tris$\mathrm{HCl}$ and $1 \mathrm{mM} \mathrm{CaCl}_{2} ; \mathrm{pH}$ ). The homogenate was agitated (200rpm; $\left.4^{\circ} \mathrm{C} ; 30 \mathrm{~min}\right)$, followed by centrifugation $\left(11,400 \mathrm{~g} ; 4^{\circ} \mathrm{C} ; 30 \mathrm{~min}\right)$. The supernatant was collected and labeled as Crude Enzyme Extract. Protein content was determined by Lowry's method Lowry et al. [14] using standard bovine serum albumin (BSA). The extract was stored at $-20^{\circ} \mathrm{C}$ in deep freezer.

\section{Clarification of the crude enzyme extract}

The proteins in the crude enzyme extract were precipitated using TCA: Acetone (1:3), ice-chilled acetone (1:3), and salt ammonium sulfate ( $30 \%$ and $80 \%$ saturation). After the addition of each precipitant, incubation was provided for $15 \mathrm{~min}$ at $-20^{\circ} \mathrm{C}$ and later centrifuged $\left(6,000 \mathrm{~g} ; 4^{\circ} \mathrm{C} ; 30 \mathrm{~min}\right)$. Only the pellet was retained. The ammonium sulfate soluble fraction was dialyzed overnight using tubing made up of eggshell membrane against the extraction buffer at $4^{\circ} \mathrm{C}$. 


\section{Purification of trypsin using gel filtration chromatography}

Protein was purified using DEAE-cellulose column chromatography. A column of dimensions $0.5 \times 5.5 \mathrm{~cm}$ was prepared in which gel slurry prepared in extraction buffer was added. The column was equilibrated with the extraction buffer, and the sample was applied @ $0.25 \mathrm{mlmin}^{-1}$. The buffer was used to elute out all the fractions which were then collected till no absorbance was detected at $280 \mathrm{~nm}$. The fraction giving highest peak was selected.

\section{Assay of activity of trypsin}

The capacity of purified trypsin to degrade amide substrate BAPNA (N- $\alpha$-benzoyl-DL-arginine p-nitroanilide) into p-nitroaniline was determined according to the method of Erlanger [15]. For this, $100 \mu \mathrm{l}$ of enzyme sample was added to an aliquot of BAPNA in tris buffer ( $\mathrm{pH}$ 8.2). The release of p-nitroaniline (yellow color) was measured at $410 \mathrm{~nm}$ after 10 second intervals for $3 \mathrm{~min}$. by spectrophotometer. One unit of amidase activity is defined as $1 \mu \mathrm{mol}$ product formed per min at $25^{\circ} \mathrm{C}$.

$$
U=\frac{\Delta A 410 \mathrm{~nm} /(\mathrm{min}) \times f \times V}{\eta \times l \times v}
$$

Where,

$\mathrm{U}=$ amidase activity units

$\mathrm{f}=$ conversion factor $\left(10^{6}\right)$

$\eta=$ extinction coefficient of p-nitroaniline i.e. 8800

$\Delta A 410 \mathrm{~nm} /(\min )=$ absorbance change at $410 \mathrm{~nm}$ per min

$\mathrm{V}=$ reaction volume $(\mathrm{ml})$

$\mathrm{l}=$ path length $(\mathrm{cm})$

$\mathrm{v}=$ volume of enzyme $(\mathrm{ml})$

\section{Enzyme kinetics}

Determination of Michaelis-Menten constant (Km) and maximum velocity of the reaction (Vmax) was done by constructing Lineweaver-Burk double reciprocal plot using GraphPad Prism software version8. From these values, turnover number (kcat) and enzyme efficiency were also calculated (kcat/Km).

\section{Determination of $\mathrm{pH}$ and temperature of trypsin}

Buffers of varying $\mathrm{pH}(0.1 \mathrm{M}$ citrate- $\mathrm{NaOH}$ : $\mathrm{pH} 4.0$ and 6.0; 0.1M Tris-HCl: $\mathrm{pH}$ 7.0, 8.0 and 8.5; 0.1M glycine- $\mathrm{NaOH}: \mathrm{pH} 10$ ) were prepared. An equal volume $(50 \mu \mathrm{l})$ of both enzyme sample and substrate were added to $900 \mu \mathrm{l}$ of buffer solution and incubated for $5 \mathrm{~min}$. at $37^{\circ} \mathrm{C}$. Henceforth, to stop the reaction $1 \mathrm{ml} 0.1 \mathrm{M} \mathrm{KOH}$ was added and the yellow color produced was measured at $405 \mathrm{~nm}$. The activity was plotted as a function of $\mathrm{pH}$ Castillo Yanez [16]. Similarly, the temperature dependency of the enzyme was calculated within a range of $20^{\circ} \mathrm{C}$ to $70^{\circ} \mathrm{C}$. The rate of BAPNA hydrolysis by the enzyme was measured as change in absorbance at $480 \mathrm{~nm} \mathrm{~min}^{-1}$ Castillo Yanez [16].

\section{Determination of molecular weight}

The molecular weight of the enzyme was found by SDS polyacrylamide gel electrophoresis (Laemmli, 1970). The method was modified by using $6 \%$ resolving gel and $4 \%$ stacking gel.

\section{Peptide fingerprinting and mass spectrometry}

Peptides of the enzyme sample were obtained by self-cleavage in the presence of $50 \mathrm{mM}$ ammonium bicarbonate buffer at $37^{\circ} \mathrm{C}$ for $12 \mathrm{hr}$. Later, desalting was done using Zip-Tip C18 (Millipore Co., Billerica, MA, USA). Using $\alpha$-cyano-4-hydroxy-cinnamic acid spotting was performed.

\section{Statistical analysis}

The experiments were performed in triplicates and their values represented as mean \pm standard deviation. Using analysis of variance (ANOVA) the data was analyzed and only those values significant above confidence level 95\% ( $\mathrm{p}<0.05)$ was accepted.

\section{Result and Discussion}

\section{Determination of protein content in crude enzyme extract}

Table 1: Seasonal variation of protein content in crude extracts.

\begin{tabular}{|c|c|c|c|}
\hline \multirow{2}{*}{ S. No. } & \multirow{2}{*}{ Sample } & \multicolumn{2}{|c|}{ Protein Content $\left(\mathrm{mg} \mathrm{ml}^{-\mathbf{1}}\right)$} \\
\cline { 3 - 4 } & & Post-Monsoon & Pre-Monsoon \\
\hline 1. & CL-I & $165.43( \pm 0.01)$ & $160.45( \pm 0.00)$ \\
\hline 2. & CI-I & $138.86( \pm 0.01)$ & $138.00( \pm 0.01)$ \\
\hline 3. & CL-II & $147.98( \pm 0.02)$ & $146.66( \pm 0.02)$ \\
\hline 4. & CI-II & $151.11( \pm 0.01)$ & $150.00( \pm 0.02)$ \\
\hline 5. & CL-III & $140.96( \pm 0.02)$ & $138.76( \pm 0.02)$ \\
\hline 6. & CI-III & $141.12( \pm 0.02)$ & $140.00( \pm 0.02)$ \\
\hline 7. & CL-IV & $175.32( \pm 0.01)$ & $171.76( \pm 0.01)$ \\
\hline 8. & CI-IV & $145.22( \pm 0.01)$ & $140.78( \pm 0.00)$ \\
\hline
\end{tabular}

The protein content was analyzed (Table 1) and it was found that the values were consistently higher in post-monsoon samples than in pre-monsoon samples. The physiological factors such as spawning, feeding, and maturation contribute towards seasonal variation in protein content Ravichandran [17]. Amongst all, the hepatic extracts exhibited a higher protein value which may be due to inclination of liver towards metabolic processes. Only in site 2 the intestinal extract exhibited $2 \%$ increase than liver. This suggests site 2 to harbor fishes from lotic habitat Tiwari \& Pandey [18]. The results were in accordance with the findings of Pilla [19] while working on viscera of Lutjaus johni. Also, Prasad [20] found similar results in marine fishes Gazza achlamys and Ariomma indica. 


\section{Clarification of crude extract}

For precipitation of the proteins present in the crude enzyme extract, different chemicals were used. Table $2 \& 3$ resp. depicts the protein content obtained and weight of pellet obtained in each case. All the precipitating agents were found resourceful as a significant amount of pellet (Table 2) was obtained in each case. Although, ammonium sulfate precipitation method resulted into highest pellet weight (591.01 mg) among all, yet it was found with lower protein content $\left(111.39 \mathrm{mg} \mathrm{ml}^{-1}\right.$ as highest value) than cold acetone precipitation method $\left(133.25 \mathrm{mg} \mathrm{ml}^{-1}\right.$ as lowest value) (Table 3). This may be because of presence of salt particles molecules along with pellet by forming hydrogen bond with precipitated protein molecules as emphasized by Purwanto [21]; Lamas [22] have also reported cold acetone precipitation method effective at initial stage of purification of trypsin from Merluccius hubbsi visceral waste.

Table 2: Measurement of pellet weight and protein precipitated by different precipitating agents.

\begin{tabular}{|c|c|c|c|c|c|c|c|c|}
\hline \multirow[b]{2}{*}{ S. No. } & \multirow[b]{2}{*}{ Method } & \multirow[b]{2}{*}{ Season } & \multicolumn{2}{|c|}{ CL-I } & \multicolumn{2}{|c|}{ CI-II } & \multicolumn{2}{|c|}{ CL-IV } \\
\hline & & & $\begin{array}{c}\text { Protein (mg } \\
\mathrm{ml}^{-1} \text { ) }\end{array}$ & $\begin{array}{l}\text { Pellet } \\
\text { Weight } \\
\text { (mg) }\end{array}$ & $\begin{array}{l}\text { Protein (mg } \\
\left.\mathrm{ml}^{-1}\right)\end{array}$ & $\begin{array}{l}\text { Pellet } \\
\text { Weight } \\
\text { (mg) }\end{array}$ & $\begin{array}{l}\text { Protein } \\
\left(\mathrm{mg} \mathrm{ml}^{-1}\right)\end{array}$ & $\begin{array}{l}\text { Pellet } \\
\text { Weight } \\
\text { (mg) }\end{array}$ \\
\hline \multirow[t]{2}{*}{1} & \multirow{2}{*}{ Cold acetone } & Post-monsoon & $\begin{array}{l}150.33 \\
( \pm 0.01)\end{array}$ & $\begin{array}{c}27.65 \\
( \pm 0.01)\end{array}$ & $\begin{array}{l}130.99 \\
( \pm 0.01)\end{array}$ & $\begin{array}{c}25.52 \\
( \pm 0.01)\end{array}$ & $\begin{array}{l}152.93 \\
( \pm 0.01)\end{array}$ & $\begin{array}{c}28.80 \\
( \pm 0.01)\end{array}$ \\
\hline & & Pre-monsoon & $\begin{array}{l}147.99 \\
( \pm 0.01)\end{array}$ & $\begin{array}{c}22.54 \\
( \pm 0.01)\end{array}$ & $\begin{array}{l}130.01 \\
( \pm 0.01)\end{array}$ & $\begin{array}{c}20.76 \\
( \pm 0.01)\end{array}$ & $\begin{array}{l}140.90 \\
( \pm 0.01)\end{array}$ & $\begin{array}{c}25.09 \\
( \pm 0.01)\end{array}$ \\
\hline \multirow[t]{2}{*}{2} & \multirow{2}{*}{$\begin{array}{c}\left(\mathrm{NH}_{4}\right)_{2} \mathrm{SO}_{4}(30 \% \\
\text { saturation })\end{array}$} & Post-monsoon & $\begin{array}{c}99.90 \\
( \pm 0.01)\end{array}$ & $\begin{array}{l}850.73 \\
( \pm 0.02)\end{array}$ & $\begin{array}{l}115.49 \\
( \pm 0.01)\end{array}$ & $\begin{array}{l}475.00 \\
( \pm 0.01)\end{array}$ & $\begin{array}{l}100.26 \\
( \pm 0.01)\end{array}$ & $\begin{array}{l}861.23 \\
( \pm 0.02)\end{array}$ \\
\hline & & Pre-monsoon & $\begin{array}{c}92.23 \\
( \pm 0.02)\end{array}$ & $845( \pm 0.01)$ & $\begin{array}{l}113.43 \\
( \pm 0.02)\end{array}$ & $\begin{array}{l}465.00 \\
( \pm 0.02)\end{array}$ & $\begin{array}{c}91.56 \\
( \pm 0.02)\end{array}$ & $\begin{array}{l}851.67 \\
( \pm 0.02)\end{array}$ \\
\hline \multirow[t]{2}{*}{3} & \multirow{2}{*}{$\begin{array}{l}\left(\mathrm{NH}_{4}\right)_{2} \mathrm{SO}_{4}(80 \% \\
\text { saturation })\end{array}$} & Post-monsoon & $\begin{array}{l}110.98 \\
( \pm 0.01) \\
\end{array}$ & $\begin{array}{l}261.08 \\
( \pm 0.01) \\
\end{array}$ & $\begin{array}{l}103.00 \\
( \pm 0.01) \\
\end{array}$ & $\begin{array}{l}237.38 \\
( \pm 0.02) \\
\end{array}$ & $\begin{array}{l}100.39 \\
( \pm 0.01) \\
\end{array}$ & $\begin{array}{l}242.23 \\
( \pm 0.01) \\
\end{array}$ \\
\hline & & Pre-monsoon & $\begin{array}{c}96.04 \\
( \pm 0.02)\end{array}$ & $\begin{array}{l}250.01 \\
( \pm 0.01)\end{array}$ & $\begin{array}{c}82.69 \\
( \pm 0.02)\end{array}$ & $\begin{array}{l}220.75 \\
( \pm 0.01)\end{array}$ & $\begin{array}{c}95.99 \\
( \pm 0.01)\end{array}$ & $\begin{array}{l}233.99 \\
( \pm 0.02)\end{array}$ \\
\hline \multirow[t]{2}{*}{4} & \multirow{2}{*}{ TCA: Acetone } & Post-monsoon & $\begin{array}{c}85.59 \\
( \pm 0.01) \\
\end{array}$ & $38.9( \pm 0.00)$ & $\begin{array}{c}92.32 \\
( \pm 0.01)\end{array}$ & $\begin{array}{c}33.70 \\
( \pm 0.02) \\
\end{array}$ & $\begin{array}{c}73.26 \\
( \pm 0.01) \\
\end{array}$ & $41( \pm 0.00)$ \\
\hline & & Pre-monsoon & $\begin{array}{c}74.47 \\
( \pm 0.01)\end{array}$ & $\begin{array}{c}29.02 \\
( \pm 0.00)\end{array}$ & $\begin{array}{c}82.00 \\
( \pm 0.02)\end{array}$ & $\begin{array}{c}24.56 \\
( \pm 0.02)\end{array}$ & $\begin{array}{c}66.78 \\
( \pm 0.01)\end{array}$ & $\begin{array}{c}32.89 \\
( \pm 0.01)\end{array}$ \\
\hline
\end{tabular}

Table 3: Determination of Peaks Obtained from Digest of CL-IV Fraction.

\begin{tabular}{|c|c|c|c|c|}
\hline S. No. & Retention Time (min) & Position & Sequence & $\mathrm{m} / \mathrm{z}$ value \\
\hline 1. & 13.93 & $5-14$ & IEVRLGEHNI & 1180.489 \\
\hline 2. & 14.01 & $117-124$ & TMFCAGYL & 905.386 \\
\hline 3. & 14.07 & $120-131$ & CAGYLEGGKDSC & 602.315 \\
\hline 4. & 24.93 & $49-56$ & LSTPASLN & 802.43 \\
\hline 5. & 25.47 & $137-140$ & GPVV & 371.227 \\
\hline 6. & 27.85 & $14-19$ & IVVNEG & 630.346 \\
\hline 7. & 41.63 & $34-100$ & $\begin{array}{l}\text { SYDSYTLDSDVMVIKLSTPASLNQYVQPISLPSGCAAAGTKCSVTGWGN- } \\
\text { TM SPTADSDKLQCLEIPI }\end{array}$ & 1761.602 \\
\hline
\end{tabular}

\section{Purification of trypsin by gel filtration chromatography}

On performing Gel Filtration Chromatography, the fraction exhibiting highest absorbance was compared with the standard and crude extract. Appearance of peak around 280nm in the crude extract indicates presence of trypsin. However, the broader peaks indicate presence of other proteins (Figure 3). A combination of Sephadex $\mathrm{G}^{-1} 00$ and DEAE-Cellulose column chromatography has been applied by Geethanjali \& Subash 2018, for purifying Labeo rohita visceral protease to obtain 13.40 -fold purity.

\section{Kinetic characteristics of trypsin in chromatographic fraction of CL-IV}

The kinetic characteristics of enzyme include study of certain parameters such as activity, specific activity, optimum $\mathrm{pH}$ and temperature, efficiency and turn over number. In the present study, activity and specific activity of trypsin for BAPNA ( $\mathrm{N}-\alpha-$ benzoyl-DL-arginine p- nitroanilide) hydrolysis was calculated as 15.54 $\mathrm{U} \mathrm{ml}^{-1}$ and $144 \mathrm{Umg}^{-1}$, resp. Using GraphPad Prism software version8, a Lineweaver-Burke plot (Figure 4) was constructed to 
find the value of $\mathrm{Km}(2.47 \mathrm{mM})$, Vmax $\left(0.40 \mu \mathrm{m}^{-1} \mathrm{~min}^{-1}\right)$ and kcat $\left(3.8 \mathrm{~s}^{-1}\right)$. These results were consistent with those of Duarte et al. 2013 while working on hepatic trypsin activity of herbivore and omnivore Siluriformes fish species. However, a correlation between digestive enzyme activity and feeding habit of fish is still not clear.

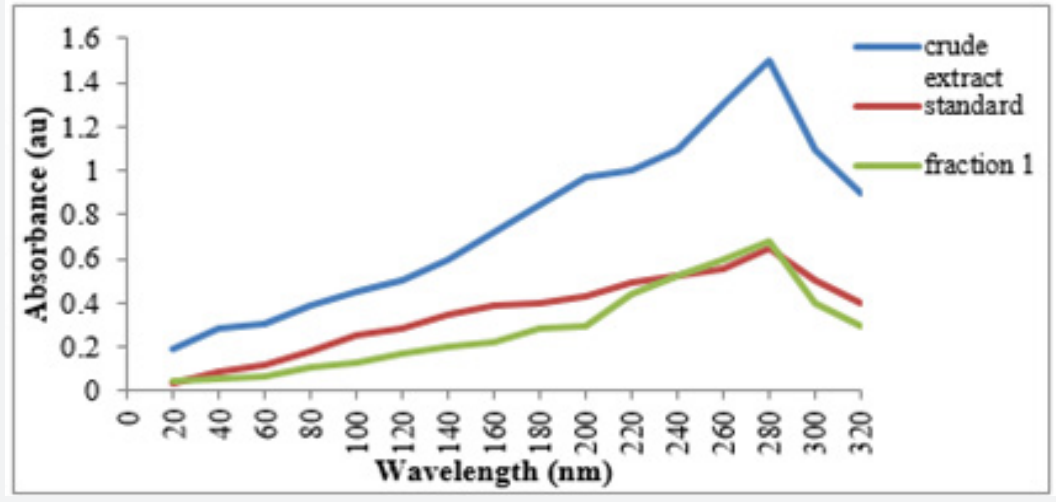

Figure 3: Absorption spectra of crude extract, Standard/commercial trypsin, and Fraction1= chromatographic fraction1

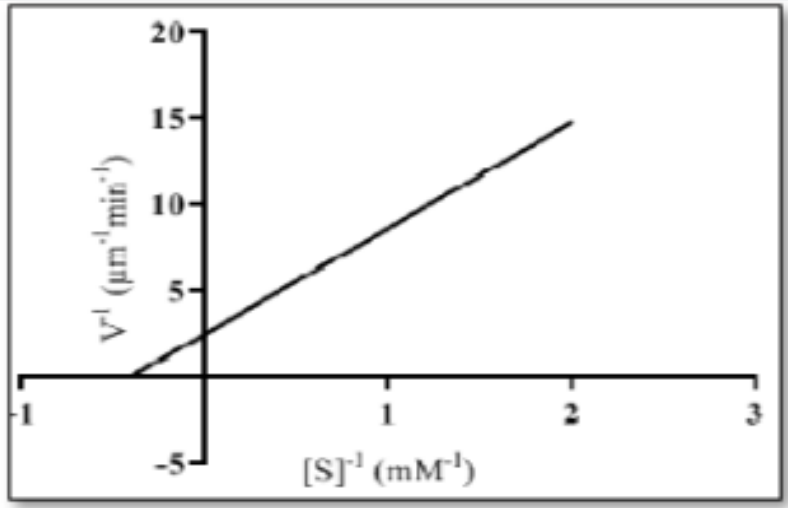

Figure 4: Lineweaver-Burk Plot of fraction CL-IV.

\section{Determination of optimum temperature}

The enzyme sample was incubated with the substrate at different temperatures $\left(20^{\circ} \mathrm{C}-70^{\circ} \mathrm{C}\right)$ and activity was studied (Figure 6). Activity of trypsin gradually increased with increasing temperature, reached maximum $\left(15.41 \mathrm{U} \mathrm{ml}^{-1}\right)$ at a temperature of $40^{\circ} \mathrm{C}$ and then decreased. The residual activity in CL-IV at temperatures $50^{\circ} \mathrm{C}$ and $60^{\circ} \mathrm{C}$ was $58.5 \%$ and $46.3 \%$ resp. but $13.1 \%$ even at $70^{\circ} \mathrm{C}$. Thus, the optimum temperature was $40^{\circ} \mathrm{C}$ and a residual activity at higher temperatures was also observed. These findings were in line with the findings of Khangembam [23]. Comparatively, a lesser residual activity (46.3\%) at $60{ }^{\circ} \mathrm{C}$ but an improved activity $(13.1 \%)$ at $70^{\circ} \mathrm{C}$ was observed. Such an observation highlights over the possibility of thermostable nature of the fish enzyme which may be due to presence of $\mathrm{Ca}^{2}+$ used in extraction buffer Bougatef [24]. Such enzymes are useful as meat tenderizing agent and detergents which requires higher working temperature (upto $70^{\circ} \mathrm{C}$ ). However, fish trypsin to be applied in detergent industries, requires prior studies of detergent compatibility Tavano [25].

\section{Determination of molecular weight}

The purified enzyme exhibited a single band on SDS-PAGE at 24KDa (Plate 1). Fish trypsin has been reported with a molecular weight in the range 20-30 KDa Khandagale [26] which depends upon their varying habitat and geographical conditions. Analysis of Peptides by Orbitrap High Resolution Liquid Chromatography Mass Spectrometry (O-HRLCMS). For a comprehensive study of the purified protein, peptide analysis was performed using Orbitrap High Resolution Liquid Chromatography Mass Spectrometry. A Total Ion Current Chromatogram (TIC) was obtained (Figure 7) and the peptide sequences were analyzed in terms of their $\mathrm{m} / \mathrm{z}$ value (Table 3). An examination of TIC by MASCOT search engine the purified enzyme exhibited $19.3 \%$ resemblance with commercial bovine trypsin. The peptide sequences were aligned (Figure 8) and compared with the sequences of other fishes using BLAST 
(Table 4). Similarly, based on the peptide sequences obtained from LC-MS, Kumazawa [27] identified the multiple sources of animal glue/collagen. They detected collagen from eight different animal sources. In the same way, He et al. [28] also demonstrated the potential of LC/MS technique in identifying common vitellogenin protein form multiple fish species [29].

Table 4: The comparison of percentage identity of the sequence of peptides with other fishes resulted from Blast.

\begin{tabular}{|c|c|c|c|c|c|c|c|}
\hline \multirow{2}{*}{ S. No. } & \multirow{2}{*}{ Sequence Fragment } & \multirow{2}{*}{ Position } & \multicolumn{5}{|c|}{ BLAST Result } \\
\hline & & & Organism & Max Score & Query Coverage & Identity & Accession Number \\
\hline \multirow{4}{*}{1} & \multirow{4}{*}{ EGTEQFI } & \multirow{4}{*}{$18-24$} & Lutjanus purpereus & 26.1 & $100 \%$ & $100 \%$ & AMW07444.1 \\
\hline & & & Papio anubis & 26.1 & $100 \%$ & $100 \%$ & XР017811734.1 \\
\hline & & & Anabas testidineus & 26.1 & $100 \%$ & $100 \%$ & XP026226638.1 \\
\hline & & & Scleropages formosus & 26.1 & $100 \%$ & $100 \%$ & XP018587676.1 \\
\hline \multirow{4}{*}{2} & \multirow{4}{*}{ YPGMIT FCAGY } & \multirow{4}{*}{$110-123$} & Cyprinus carpio & 52.8 & $100 \%$ & $100 \%$ & BAL04386.1 \\
\hline & & & Labeo rohita & 52.8 & $100 \%$ & $100 \%$ & AHY00277.1 \\
\hline & & & Carrasius auratus & 52.8 & $100 \%$ & $100 \%$ & XP026104836.1 \\
\hline & & & Danio rerio & 52.8 & $100 \%$ & $100 \%$ & NP955899.2 \\
\hline \multirow{2}{*}{3} & \multirow{2}{*}{ MFCAGY LE } & \multirow{2}{*}{$118-125$} & Amphiprion ocellaris & 31.6 & $100 \%$ & $100 \%$ & XP023119402.1 \\
\hline & & & Salmo salar & 31.6 & $100 \%$ & $100 \%$ & XP014057038.1 \\
\hline \multirow{4}{*}{4} & \multirow{4}{*}{$\begin{array}{c}\text { NSYPGM } \\
\text { ITNTMF } \\
\text { CAGY }\end{array}$} & \multirow{4}{*}{$108-123$} & Cyprinus carpio & 58.7 & $100 \%$ & $100 \%$ & BAL04386.1 \\
\hline & & & Labeo rohita & $58 . .7$ & $100 \%$ & $100 \%$ & AHY00277.1 \\
\hline & & & Carrasius auratus & 58.7 & $100 \%$ & $100 \%$ & XP026104836.1 \\
\hline & & & Salmo salar & 58.7 & $100 \%$ & $100 \%$ & XP014010924.1 \\
\hline
\end{tabular}

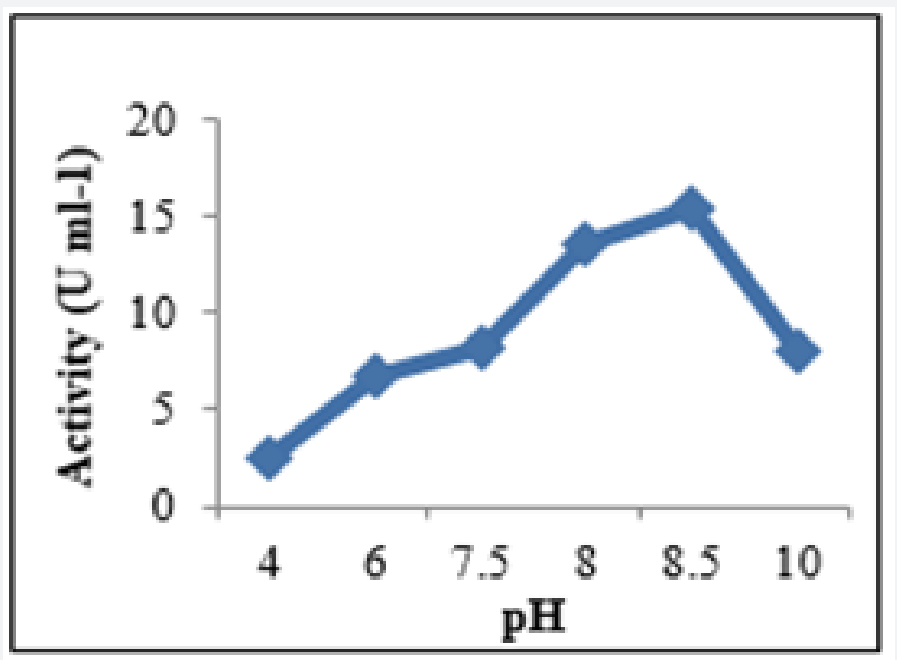

Figure 5: Showing optimum pH for CL-IV.

\section{Conclusion}

The kinetic parameters and results of LCMS relate the isolated trypsin with that of other fish and mammalian trypsin. The effect of $\mathrm{pH}$ and temperature highlights the potential application of this enzyme in detergent and in the food industry. The industrial detergent enzyme market has been expected to exhibit a growth rate of $11.3 \%$. Thus, a more beneficial and productive use of fish processing waste could be made in an eco-friendly manner. In relevance of the study, the fish processing industries could be suggested to set up a unit in the near vicinity of fish catch so that the waste can be quickly collected and processed into industrially important enzyme. 


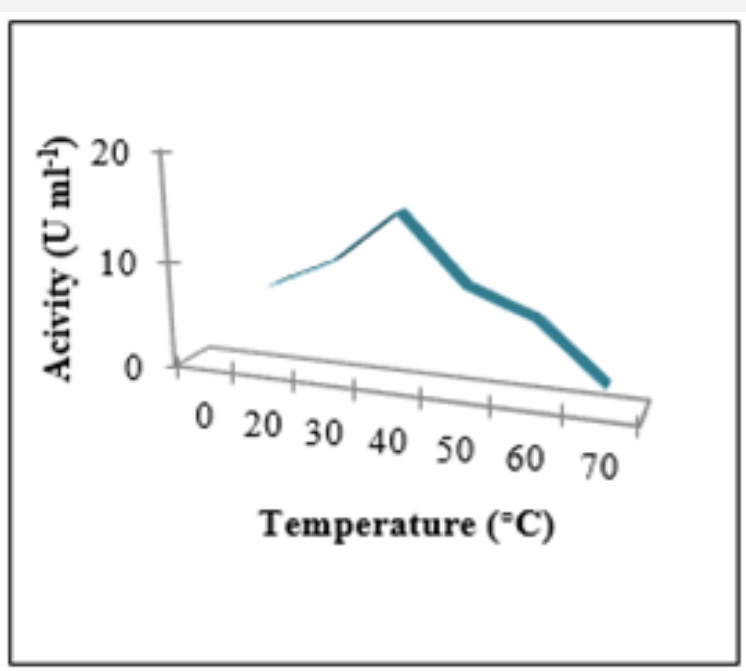

Figure 6: Showing optimum temperature for CL-IV.

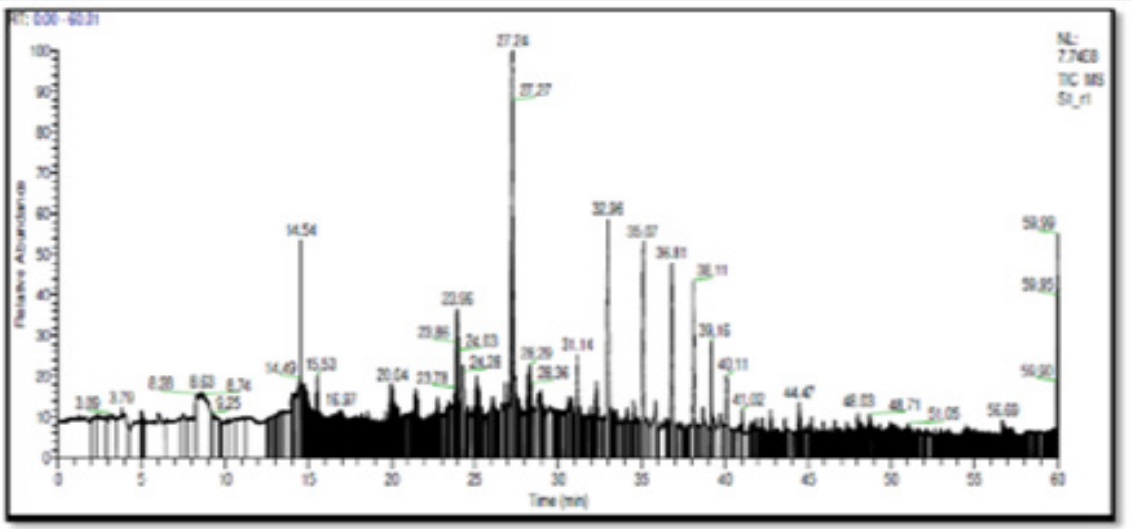

Figure 7: Total lon Current Chromatogram of CL-IV.

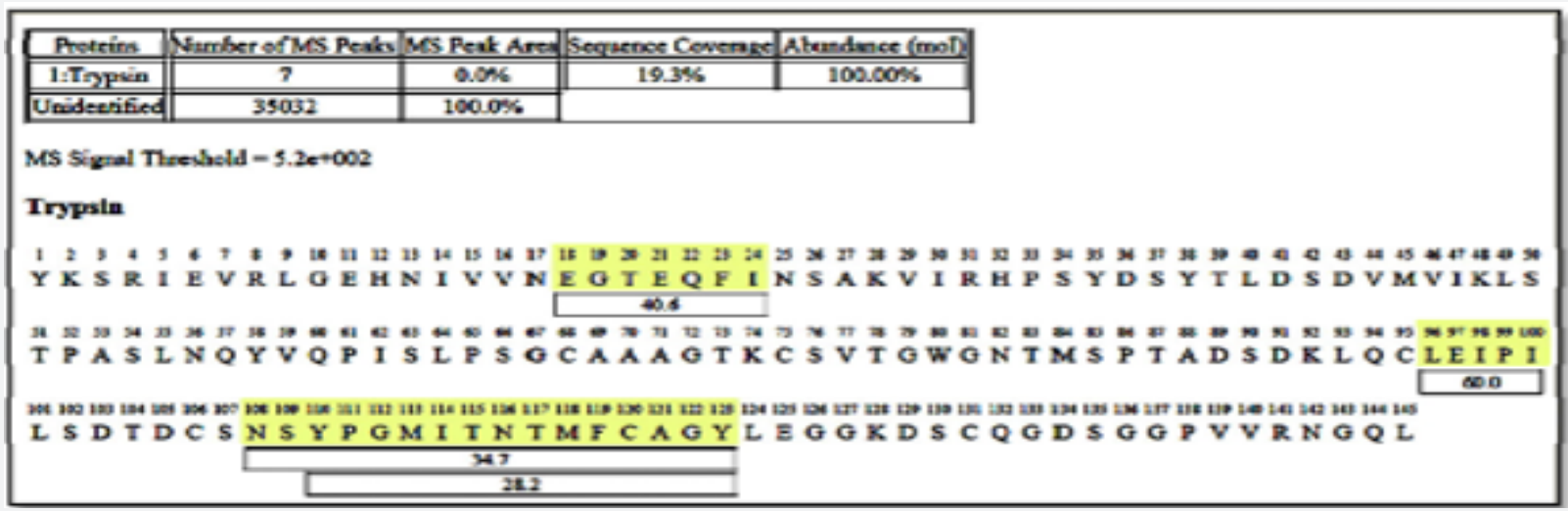

Figure 8: Sequence Coverage Map of digest of CL-IV fraction. 


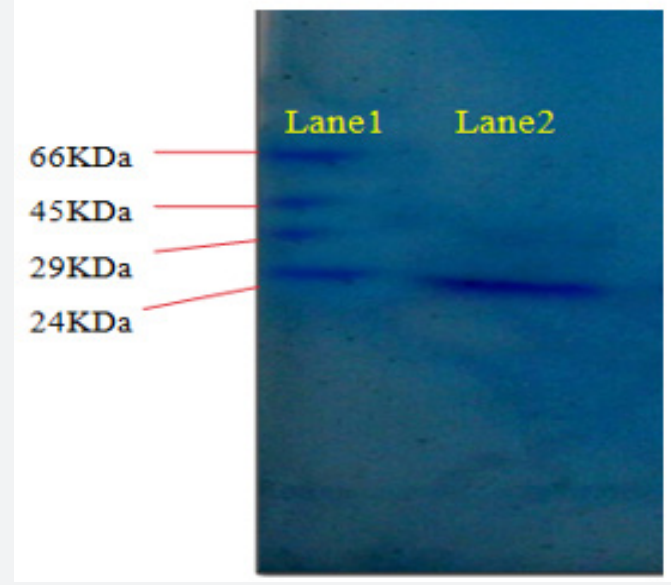

Plate 1: Electrophoretogram of CL-IV (lane2) running along with protein marker (lane1).

\section{References}

1. Kanno G, Klomkalo S, Kumagai Y, Kishimura H (2018) A thermostable trypsin from freshwater fish Japanese dace (Tribolodon hakonensis): a comparison of the primary 2 structures among fish trypsins. Fish physiology and biochemistry 45(2): 561-571.

2. Santos CWV, da Costa Marques ME, de Araujo Tenorio H, Carvalho de Miranda E, Vieira Pereira HJ (2016) Purification and characterization of trypsin from Luphiosilurus alexandri pyloric cecum. Biochemistry and Biophysics Report 8: 29-33.

3. Aissaoui N, Marzouki MN, Abidi F (2017) Purification and biochemical characterization of a novel intestinal protease from Scorpaena notata. International Journal of Food Property 20: 387- 395.

4. Das SN, Neeraja Ch, Sarma PVSRN, Madhuprakash J, Purushotham P, et al. (2012) Microbial Chitinases for Chitin Waste Management. In: Microorganisms in Environmental Management. Microbes and Environment. ( $1^{\text {st }}$ edn), Springer Netherlands publishers, pp. 135-147.

5. Wang W, Gao ZX, Zhang N, Shi Y, Xie XL, et al. (2010) Purification and characterization of trypsin from the intestine of hybrid tilapia (Oreochromis niloticus $x$ O. aureus). Journal of Agricultural Food Chemistry 58(1): 655-659.

6. Jellouli K, Bougatef A, Daassi D, Balti R, Barkia A, et al. (2009) New alkaline trypsin from the intestine of Grey triggerfish (Balistes capricus) with high activity at low temperature: purification and characterization Food Chemistry 116(3): 644-650.

7. Silva JF, Esposito TS, Marcuschi M, Rebeiro K, Cavalli RO, et al. (2011) Purification and partial characterization of a trypsin from the processing waste of the silver mojarra (Diapterus rhombeus). Food Chemistry 129(3): 777-782.

8. Unajak S, Meesawat P, Paemanee A, Areechon N, Engkagul A, et al. (2012) Characterisation of thermostable trypsin and determination of trypsin isozymes from intestine of Nile tilapia (Oreochromis niloticus L.) Food Chemistry 134(3): 1533-1541.

9. Costa HMS, Freitas-Júnior ACV, Amaral IP, Hirata IY, Paiva PMG, et al (2013) Metal-sensitive and thermostable trypsin from the crevalle jack (Caranx hippos) pyloric caeca: purification and characterization. Chemistry Central Journal 7: 166.

10. Blanco M, Simpson BK, Perez-Martín RI, Sotelo GC (2014) Isolation and partial and characterization of trypsin from pancreas of small-spotted catshark (Scyliorhinus canicula) Journal of Food Biochemistry 38(2): 196- 206.

11. Khandagale AS, Sarojini BK, Kumari SN, Joshi SD, Nooralabettu K (2015) Isolation Purification and Biochemical Characterization of Trypsin from Indian Mackerel (Rastralliger kanagurta). Journal of Aquatic Food Product Technology 24: 354-367.

12. Toyota E, Kenneth KSN, Kuninaga S, Sekizaki H, Itoh K, et al. (2002) Crystal structure and nucleotide sequence of an anionic trypsin from Chum Salmon (Oreochromis keta) in comparison with Atlantic Salmon (Salmo salar) and bovine trypsin. Journal of Molecular Biology 324(3): 391-397.

13. Simpson BK, Haard NF (1985) Characterization of trypsin fraction from cunner (Tautogolabrus adspersus). Comparative Biochemistry and Physiology 80(3): 475-480.

14. Lowry OH, Rosebrough NJ, Farr AL, Randall RJ (1951) Protein measurement with Folin phenol reagent. Journal of Biology and Chemistry 193: 265-275.

15. Erlanger BF, Kokowsky N, Cohen W (1961) The preparation and properties of two new chromogenic substrates of trypsin. Archives of Biochemistry and Biophysics 95: 271-278.

16. Castillo Yáñez FJ, Pacheco Aguilar R, García Carreño FL, Navarretedel Toro MA, López MF (2006). Purification and biochemical characterization of chymotrypsin from the viscera of monterey sardine (Sardinops sagax caeruleus). Food Chemistry 99(2): 252 -259.

17. Ravichandran S, Kumaravel K, Pamela Florence E (2011) Nutritive composition of some edible fin fishes, International Journal of Zoological Research 7(3): 241-251.

18. Tiwari CG, Pandey VS (2014) Studies of hematology and histology in Labeo rohita infected with cutaneous columnaris disease. Records of the zoological Survey of India 114(1): 151-157.

19. Pilla S, Ratnakala M, Vijaya lakshmi M, Sree Ramulu K (2014) Biochemical Compositions in Muscle and Liver of Normal and Infected Fish of Lutjanus johni off Visakhapatnam Coast. International Journal of Engineering and Science 4(9): 38-42.

20. Prasad SK, Prasad NV, Venkateswarlu Ch (2017) Seasonal variations in the biochemical composition of muscle and liver of marine fishes, Gazza achlamys and Ariomma indica from Visakhapatnam coast, South India. International Journal of Bioassays 6: 5407-5414. 
21. Purwanto MGM (2016) The Role and Efficiency of Ammonium Sulphate Precipitation in Purification Process of Papain Crude Extract. Procedia Chemistry 18: 127-131.

22. Lamas DL, Yeannes MI, Massa AE (2015) Partial purification of proteolytic enzymes and characterization of trypsin from Merluccius hubbsi by-products. International Journal of Food and Nutritiona Sciences 4(5): 121-130.

23. Khangembam BK, Sharma KYVR, Chakrabarty R (2012) Purification and Characterization of trypsin from the digestive system of carp Catla catla (Hamilton). International Aquatic Research 4(9): 1-12.

24. Bougatef A (2013) Trypsins from fish processing waste: characteristics and biotechnological applications- comprehensive review. Journal of Cleaner Production 57(15): 257-265.

25. Tavano OL, Murcia AB, Secundo F, Lafuente F (2018) Biotechnological Applications of Proteases in Food Technology. Comprehensive Reviews in Food Science and Food Safety 17(2): 412-436.
26. Khandagale AS, Mundodi L, Sarojini BK (2017) Isolation and characterization of trypsin from fish viscera of Oil Sardine (Sardinella longiceps). International Journal of Fisheries and Aquatic Studies 5(2): 33-37.

27. Kumazawa Y, Taga Y, Takashima M, Hattori S (2018) A Novel LCMS method using collagen marker peptides for species identification of glue applicable to samples with multiple animal origins. Heritage Science 6: 1-9.

28. He P, Matich EK, Yonkos LT, Friedman AE, Gokcumen GEA, et al. (2019) Mass spectrometry-based detection of common vitellogenin peptides across fish species for assessing exposure to estrogenic compounds in aquatic environments. Science of the total Environment 646: 400-408.

29. Laemmli UK (1970) Cleavage of structural proteins during assembly of the head of bacteriophage T4. Nature 227: 680-685.

30. Vannabun A, Ketnawa S, Phongthai S, Benjakul S, Rawdkuen S (2014) Characterization of acid and alkaline proteases from viscera of farmed giant catfish. Food Bioscience 6: 9-16.

\section{Your next submission with Juniper Publishers will reach you the below assets}

- Quality Editorial service

- Swift Peer Review

- Reprints availability

- E-prints Service

- Manuscript Podcast for convenient understanding

- Global attainment for your research

- Manuscript accessibility in different formats

( Pdf, E-pub, Full Text, Audio)

- Unceasing customer service

Track the below URL for one-step submission https://juniperpublishers.com/online-submission.php 